\title{
V. Klientelsysteme in Spanien
}

\author{
Einleitung zur Diskussion
}

\author{
Helmut G. Koenigsberger
}

\section{Queries on Spain}

The excellent papers by Professor Pérez-Picazo and Professor Lemeunier make a very suitable ending for this colloquium for two reasons:

1. they show patronage and clientage at a low social level and the interconnections of this level with high politics;

2. they show this over a much longer period of time than any of the other papers has attempted to do, viz. from the 15th to the 20th centuries.

a) We are shown very clearly the basic origin of the clientage system in the early modern period: the need for the central monarchy (or government) of a large country to rely on those who have local power. This was particularly important in Murcia. Owing to the date of the reconquista of this part of Spain, the 13th century, royal power appeared late in this province. During the reconquest vast areas of land had been distributed to relatively few people. At the same time there was no local landed nobility who commanded traditional and immediate influence in the area. Effective local power or influence therefore lay below the aristocratic level.

Queries: were the great noble families, such as the Fajardo-Los Vélez, so grand and so far away that, like the king himself, they needed local help? How did this pattern differ, if at all, from the position in the settlements in East Elbia?

b) In the absence of a local nobility, local authority tended to lie with the bandos. The bandos were a mixture of clan, family and clientage networks or linkages. In the absence of effective government police or military power, they tended to fight each other and to prevent the unbiased administration of justice by the classic methods of bringing pressure on witnesses and often also on the judges.

Query: why was pre-Reformation Scotland more peaceful? or was it really? Were the settlements earlier than in southern Spain?

c) The rivalries and struggles of the bandos tended to be channelled into the patterns of the conflicts higher up on the social scale, the conflicts of the high nobility (Aside: and since this is a very common phenomenon in late-medieval and early mod- 
ern Europe, I was earlier on sceptical of a theory which claimed that the mass of the population of Florence was concerned only with the affairs of their own quarter or neighbourhood of the city).

d) The papers gave indications of important changes of these patterns through time. These changes depended on the conjunctures of certain conditions, developments or events. The most important of these were four

(1) economic difficulties

(2) waves of banditry

(3) transformations of municipal institutions

(4) ups and downs of the effectiveness of the state apparatus.

e) Two constants should be noted:

(1) the struggles between the bandos were not anti-royalist

(2) the parties tended to close ranks when the oligarchy of those actually holding power and leading the bandos was attacked.

f) Transformations in the 19th century: the bandos now affiliate to the political parties.

In each small town one cacique still tends to hold control and, therefore, only one political party. 